\title{
Sistem Informasi Manajemen Proyek PT. Samudera Perkasa Konstruksi Berbasis Web
}

Meidyan Permata Putri, Bobby

Sekolah Tinggi Manajemen Informatika dan Komputer Palcomtech, Indonesia

\section{Article Info}

Article history:

Received, 11 March 2020

Revised, 5 August 2020

Accepted, 8 August 2020

\section{Kata Kunci:}

Sistem Informasi

Manajemen Proyek

Web

Pengolahan Proyek

Waterfall

\begin{abstract}
ABSTRAK
Perseroan Terbatas (PT) Samudera Perkasa Konstruksi merupakan perusahaan yang bergerak pada bidang jasa pelaksanaan. Pengolahan proyek selama ini dilakukan dengan menyimpan data saja, namun hanya terbatas pada data proyek, sehingga data penggunaan dan perawatan proyek tidak terdokumentasi, pada saat ini PT. Samudera Perkasa Konstruksi belum memiliki sistem pengolahan data yang baik dan mempunyai kelemahan memungkinkan terjadinya kesalahan pencatatan dan perhitungan seperti kesalahan pembuatan faktur dan membutuhkan waktu lama untuk mencari informasi yang dibutuhkan, baik itu dalam proses dokumentasi, kemajuan proyek hingga melakukan pencatatan transaksi proyek, sebagian sudah terkomputerisasi tapi belum tersistem, sehingga terdapat masalah yang timbul, diantaranya terjadinya ketidaksesuaian pada rencana, progres proyek, realisasi proyek dan proses perhitungan biaya dapat dioptimalkan. Peneliti menggunakan metode waterfall sebagai pengembangan sistem, ada lima tahapan yang digunakan yaitu communication, planning, modelling, construction, deployment. Penelitian ini dilakukan bertujuan untuk membuat sebuah sistem informasi manajemen proyek, yang dapat mempermudah pihak perusahaan untuk mengolah data dan memanajemen data proyek.
\end{abstract}

\section{ABSTRACT}

Keywords:

Information System Project Management Web

Project Processing

Waterfall

PT. Perkasa Konstruksi is a company engaged in the field of Implementation Services. Project processing so far has been done by storing data only, but only limited to project data, so that the project usage and maintenance data is not documented, at this time PT. Samudera Perkasa Construction does not have a good data processing system and has a weakness that allows the recording and calculation errors such as invoicing errors and takes a long time to find the information needed, both in the documentation process, project progress to record project transactions, some are computerized but not yet systemized, so that there are problems that arise, including the occurrence of discrepancies in plans, project progress, project realization and the cost calculation process can be optimized. Researchers use the Waterfall Method as a system development, there are five stages used, namely communication, planning, modeling, construction, deployment. This research was conducted aiming to create a Project Management Information System, which can facilitate the company to process and manage project data.

This is an open access article under the CC BY-SA license.

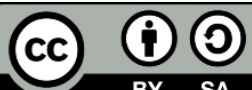

\section{Penulis Korespondensi:}

Meidyan Permata Putri,

Program Studi Sistem Informasi,

Sekolah Tinggi Manajemen Informatika dan Komputer Palcomtech,

Email: meidyan_permata@palcomtech.ac.id 


\section{PENDAHULUAN}

Perkembangan teknologi informasi saat ini dapat mempengaruhi efektivitas operasional pada perusahaan atau organisasi. Teknologi informasi berbasis website merupakan salah satu dari banyak perangkat yang digunakan manajer dalam mengantisipasi perubahan [1]. Website adalah sekumpulan halaman yang terdiri dari beberapa halaman yang berisi informasi dalam bentuk data digital baik berupa teks, gambar, video, audio, dan animasi lainnya yang disediakan melalui jalur koneksi internet [2]. Website merupakan sebuah teknologi informasi yang diterapkan dan dimanfaatkan sebagai salah satu solusi untuk meminimalisir tingkat kesalahan pada pengguna, baik pelayanan kepada konsumen maupun dalam memanajemen distribusi informasi dan data kepada sesama karyawan perusahaan [3]

PT. Samudera Perkasa Konstruksi selama ini dalam pengelolaan proyek, masih melakukan pencatatan atau penyimpanan data menggunakan Micorsoft Word dan Microsoft Excel. Pengolahan data yang belum terstruktur dengan baik mempunyai kelemahan yaitu terjadinya kesalahan pencatatan dan perhitungan seperti kesalahan pembuatan faktur dan membutuhkan waktu lama untuk mencari informasi yang dibutuhkan. Proses dokumentasi, progres proyek hingga melakukan pencatatan transaksi proyek sebagian sudah terkomputerisasi tapi belum tersistem, sehingga muncul masalah yaitu terjadinya ketidaksesuaian pada rencana, progres proyek, realisasi proyek dan proses perhitungan biaya. Proses perhitungan perlu dioptimalkan karena di dalam pembukuan bisa saja ada transaksi yang terlewat karena banyaknya transaksi pembelian bahan, hal ini menyebabkan pelaksana proyek menjadi kewalahan dalam pembukuan transaksi pembelian bahan bangunan yang menyebabkan kesulitan dalam menentukan keuntungan yang didapat dari setiap proyek dan berimbas pada laporan kantor kepada konsumen pemberi proyek dalam hal harga material atau harga jasa yang diberikan kepada konsumen, serta proses saat pengisian dokumen laporan proyek.

Sistem informasi manajemen merupakan salah satu bagian dari sistem informasiberbasis komputer yang menyediakan informasi bagi para pengguna yang memiliki kebutuhan yang sama [4]. Sistem informasi manajemen adalah sebuah rangkaian yang terorganisasi dari sejumlah bagian atau komponen yang secara bersama-sama berfungsi atau bergerak menghasilkan informasi untuk digunakan dalam manajemen perusahaan. Masukan bagi sistem informasi manajemen adalah data kemudian prosesnya adalah pengumpulan, penyimpanan, dan pengolahan data tersebut; sedangkan keluarannya adalah informasi []. Sistem informasi manajemen mendukung manajer fungsional dengan menyediakan laporan berkala yang termasuk rangkuman, perbandingan, dan statistik lain [6]. Tujuan utama dari manajemen proyek adalah agar proyek dapat dilaksanakan dengan efisien, tepat waktu, dan mencapai hasil yang diinginkan. Oleh karena itu, peran perencanaan dalam suatu proyek sangat penting, segala sesuatu harus dimulai dari rencana dan harus disepakati bersama antara para stakeholder yang terlibat pada proyek [7].

Proyek yang dilaksanakan secara temporer tentu perlu diatur dan dikendalikan dengan baik. Untuk melakukan pengaturan dan pengendalian diperlukan kaidah-kaidah yang menjadi pedoman untuk pelaksanaannya. "Manajemen proyek adalah aplikasi dari pengetahuan, keahlian, alat dan teknik untuk melaksanakan aktivitas sesuai dengan ke-butuhan proyek" [ㅁ].

\section{METODE PENELITIAN}

Metode waterfall adalah model sekuensial linier (sequential Linear) atau alur hidup klasik (classic life cycle) [9]. Waterfall memiliki lima tahap atau fase yang dilakukan secara iteratif [10]. Waterfall yang didasarkan pada kebutuhan perusahaan untuk pengolahan data dan informasi terkait pada prosedur dan pelaksanaan teknis pekerjaan [11]. Adapun tahapan-tahapan yang dimaksud adalah sebagai berikut [12]:

\subsection{Communication}

Langkah pertama diawali dengan komunikasi kepada konsumen atau pengguna. Langkah awal ini merupakan langkah penting karena menyangkut pengumpulan informasi tentang kebutuhan konsumen atau pengguna.

\subsection{Planning}

Setelah proses communication ini, kemudian menetapkan rencana untuk pengerjaan software yang meliputi tugas-tugas teknis yang akan dilakukan, risiko yang mungkin terjadi, sumber yang dibutuhkan, hasil yang akan dibuat, dan jadwal pengerjaan.

\subsection{Modelling}

Pada proses modeling ini menerjemahkan syarat kebutuhan ke sebuah perancangan perangkat lunak yang dapat diperkirakan sebelum dibuat coding. Proses ini berfokus pada rancangan struktur data, arsitektur software, representasi interface, dan detail (algoritma) procedural. 


\subsection{Construction}

Construction merupakan proses membuat kode (code generation). Coding atau pengkodean merupakan penerjemahan desain dalam bahasa yang bisa dikenali oleh komputer. Programmer akan menerjemahkan transaksi yang diminta oleh user. Tahapan inilah yang merupakan tahapan secara nyata dalam mengerjakan suatu software, artinya penggunaan komputer akan dimaksimalkan dalam tahapan ini. Setelah pengkodean selesai maka akan dilakukan testing terhadap sistem yang telah dibuat. Tujuan testing adalah menemukan kesalahan-kesalahan terhadap sistem tersebut untuk kemudian bisa diperbaiki.

\subsection{Deployment}

Tahapan ini bisa dikatakan final dalam pembuatan sebuah software atau sistem. Setelah melakukan analisis, desain dan pengkodean maka sistem yang sudah jadi akan digunakan user. Kelima tahapan metode waterfall pada Gambar 1:

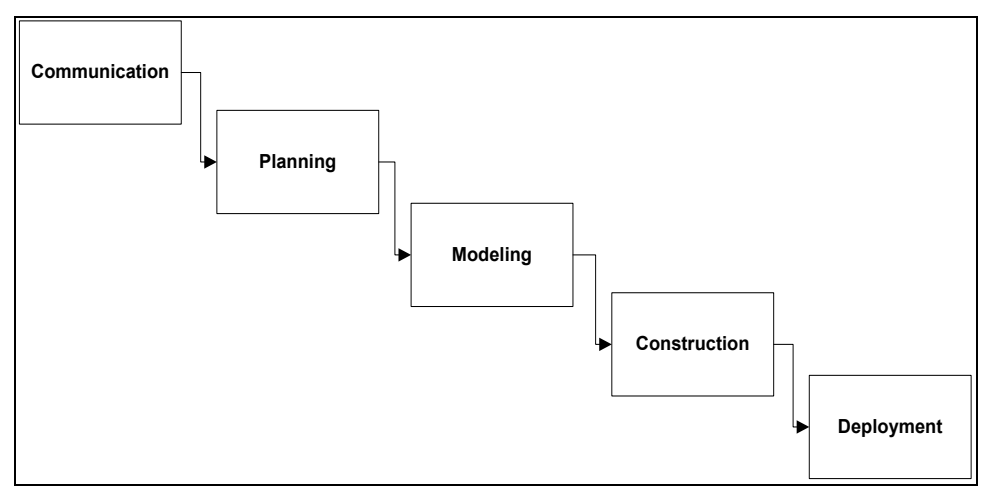

Gambar 1. Metode Waterfall [13]

\section{HASIL DAN ANALISIS}

Hasil yang didapatkan berdasarkan dari penelitian yang dilakukan di PT. Samudera Perkasa Konstruksi Teknik, pengembangan sistem pada penelitian ini menggunakan metode waterfall yang memiliki tahapan yaitu dimulai dari spesifikasi kebutuhan pengguna (communication), melalui tahap perencanaan (planning), pemodelan (modeling), konstruksi (construction), serta pada saat penyerahan sistem ke pengguna atau pelanggan (deployment), yang diakhiri dengan dukungan dari pihak perusahaan berkelanjutan pada sistem yang dihasilkan.

\subsection{Communication}

Pada tahap komunikasi peneliti melakukan wawancara dengan Bapak Muhammad Abdullah Sidik selaku Direktur, peneliti mendapatkan hasil bahwa selama ini dalam pengelolaan proyek, masih melakukan pencatatan atau penyimpanan data menggunakan Microsoft Word dan Microsoft Excel. Pengolahan data yang belum terstruktur dengan baik dan mempunyai kelemahan memungkinkan terjadinya kesalahan pencatatan dan perhitungan seperti kesalahan pembuatan faktur dan membutuhkan waktu lama untuk mencari informasi yang dibutuhkan, baik itu dalam proses dokumentasi, progres proyek hingga melakukan pencatatan transaksi proyek, sebagian sudah terkomputerisasi tapi belum tersistem, sehingga terdapat masalah yang timbul, diantaranya terjadinya ketidaksesuaian pada rencana, progres proyek, realisasi proyek dan proses perhitungan biaya dapat dioptimalkan, karena di dalam pembukuan, bisa saja ada transaksi yang terlewat karena banyaknya transaksi pembelian bahan, hal ini menyebabkan pelaksana proyek menjadi kewalahan dalam pembukuan transaksi pembelian bahan bangunan yang menyebabkan kesulitan dalam menentukan keuntungan yang didapat dari setiap proyek, dan berimbas pada laporan kantor kepada konsumen pemberi proyek dalam hal harga material atau harga jasa yang diberikan kepada konsumen, serta proses saat pengisian dokumen laporan proyek.

\subsection{Planning}

Terdapat flowchart yang berjalan yaitu alur proses pengajuan proyek, pembuatan RAB (rencana anggaran biaya), pembayaran, dan progres proyek. Berikut ini penjelasan dari alur laporan yang berjalan. 


\subsubsection{Flowchart Pengajuan Proyek}

Flowchart pengajuan proyek dapat dilihat pada Gambar 2.

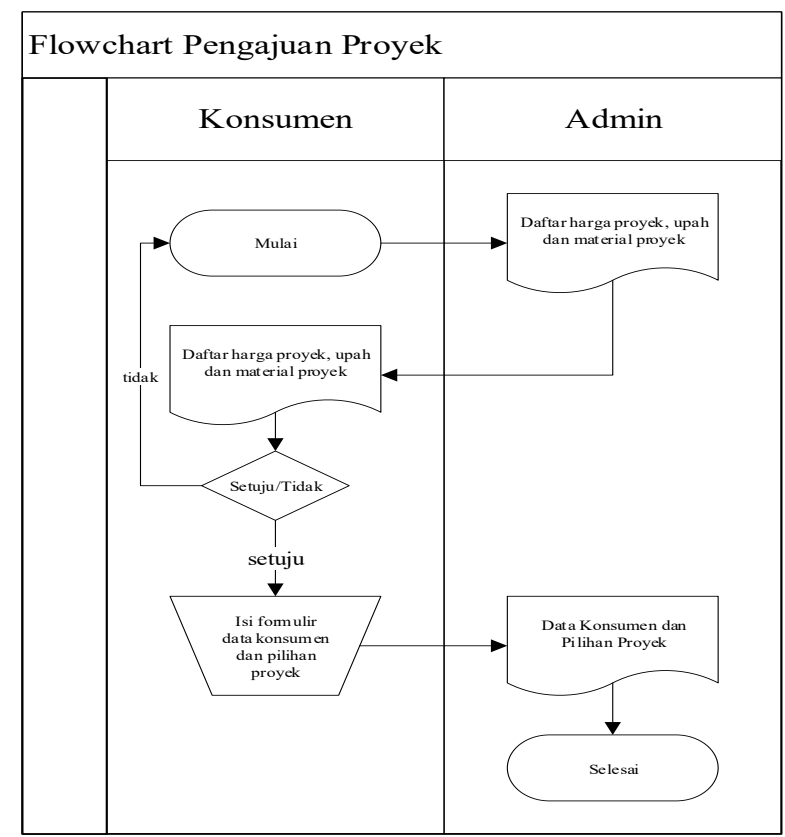

Gambar 2. Flowchart pengajuan proyek

Berdasarkan Gambar 2 flowchart pengajuan proyek yang berjalan dijelaskan sebagai berikut:

1. Saat konsumen ingin melakukan pembuatan sebuah proyek, konsumen melihat terlebih dahulu harga proyek yang ditawarkan.

2. Admin memperlihatkan daftar harga proyek, upah, dan material proyek.

3. Setelah melihat daftar harga, jika konsumen setuju, maka akan mengisi formulir data konsumen dan pilihan proyek.

4. Kemudian admin menerima formulir data konsumen dan pilihan proyek, kemudian diberikan kepada keuangan.

\subsection{Modeling}

Perancangan sistem yang dibangun dengan pemodelan data flowchart, data flow diagram (DFD), dan entity relationship diagram (ERD) merupakan bahasa visual untuk pemodelan dan komunikasi mengenai sebuah sistem dengan menggunakan diagram dan teks-teks pendukung. Adapun penjelasaan tahapan-tahapan data flowchart, DFD, dan ERD yang diusulkan seperti berikut ini.

\subsubsection{Flowchart}

Flowchart merupakan urutan logika dari suatu prosedur pemecahan masalah, sehingga flowchart merupakan langkah-langkah penyelesaian masalah yang dituliskan dalam simbol-simbol tertentu. Diagram alir ini akan menunjukkan alur didalam program secara logika. Flowchart bertujuan untuk menggambarkan suatu tahapan penyelesaian masalah sederhana, terurai, rapi, dan jelas menggunakan simbol-simbol yang telah ditentukan [14]. Flowchart alur yang diusulkan adalah alur proses hak akses sistem informasi manajemen proyek PT. Samudera Perkasa Konstruksi. 


\section{Flowchart Pengajuan Proyek}

Flowchart pengajuan proyek yang diusulkan diperlihatkan pada Gambar 3.

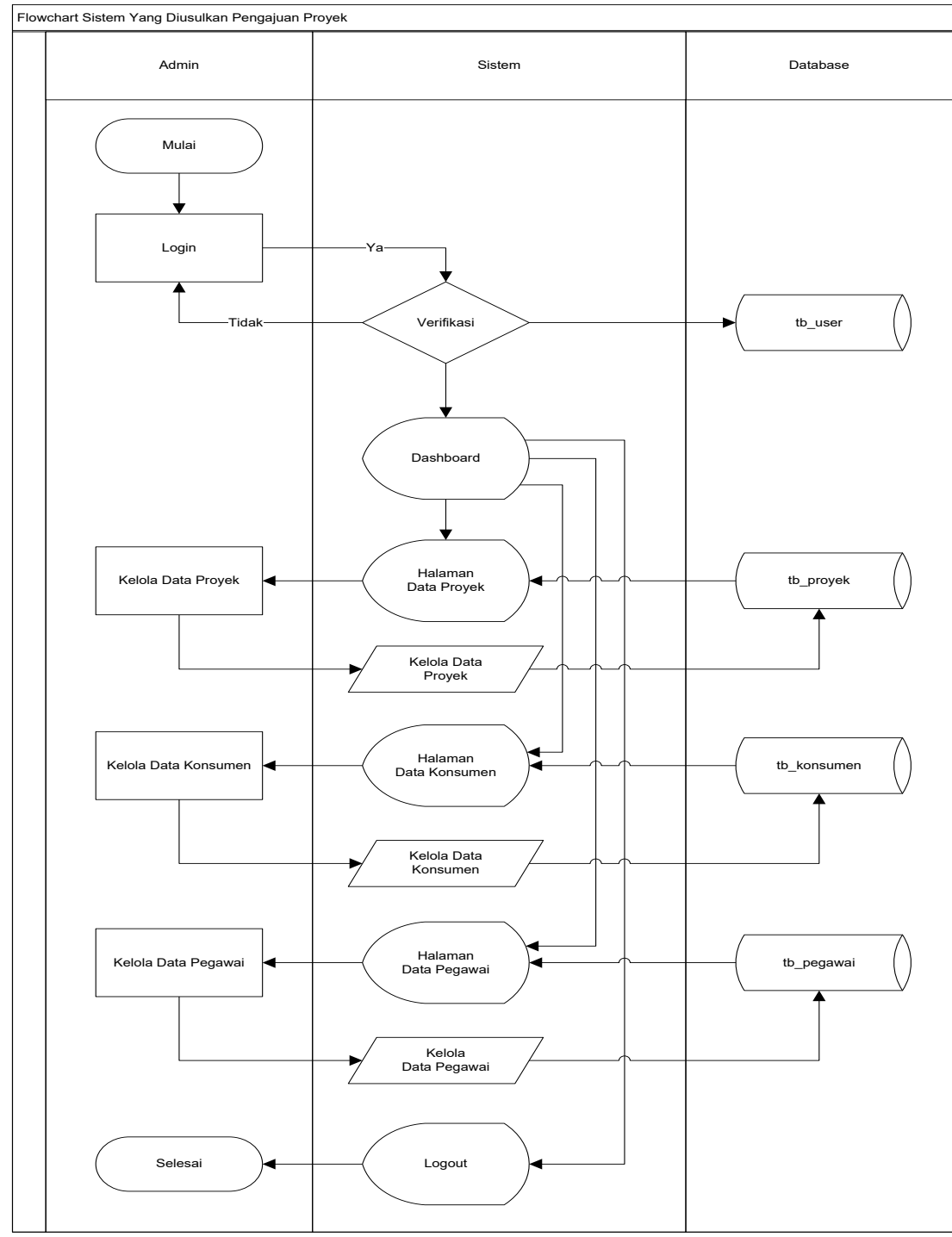

Gambar 3. Flowchart pengajuan proyek yang diusulkan

Berdasarkan Gambar 3 dari flowchart pengajuan proyek yang diusulkan adalah:

1. Admin melakukan login, jika berhasil login akan masuk pada halaman utama dan jika tidak akan tetap di form login.

2. Admin melakukan pengelolaan yakni input data, edit data dan melihat informasi, antara lain: kelola data proyek, kelola pegawai, dan kelola data konsumen.

3. Admin melakukan logout.

\section{Flowchart Progress Proyek}

Flowchart progress proyek yang diusulkan diperlihatkan pada Gambar 4. Penjelasan dari Gambar 4 flowchart progress proyek yang diusulkan adalah:

1. Keuangan melakukan login, jika berhasil login akan masuk pada halaman utama dan jika tidak akan tetap di form login.

2. Keuangan melakukan pengelolaan yakni input data, edit data dan lihat informasi, antara lain: kelola progress proyek.

3. Keuangan melakukan logout. 


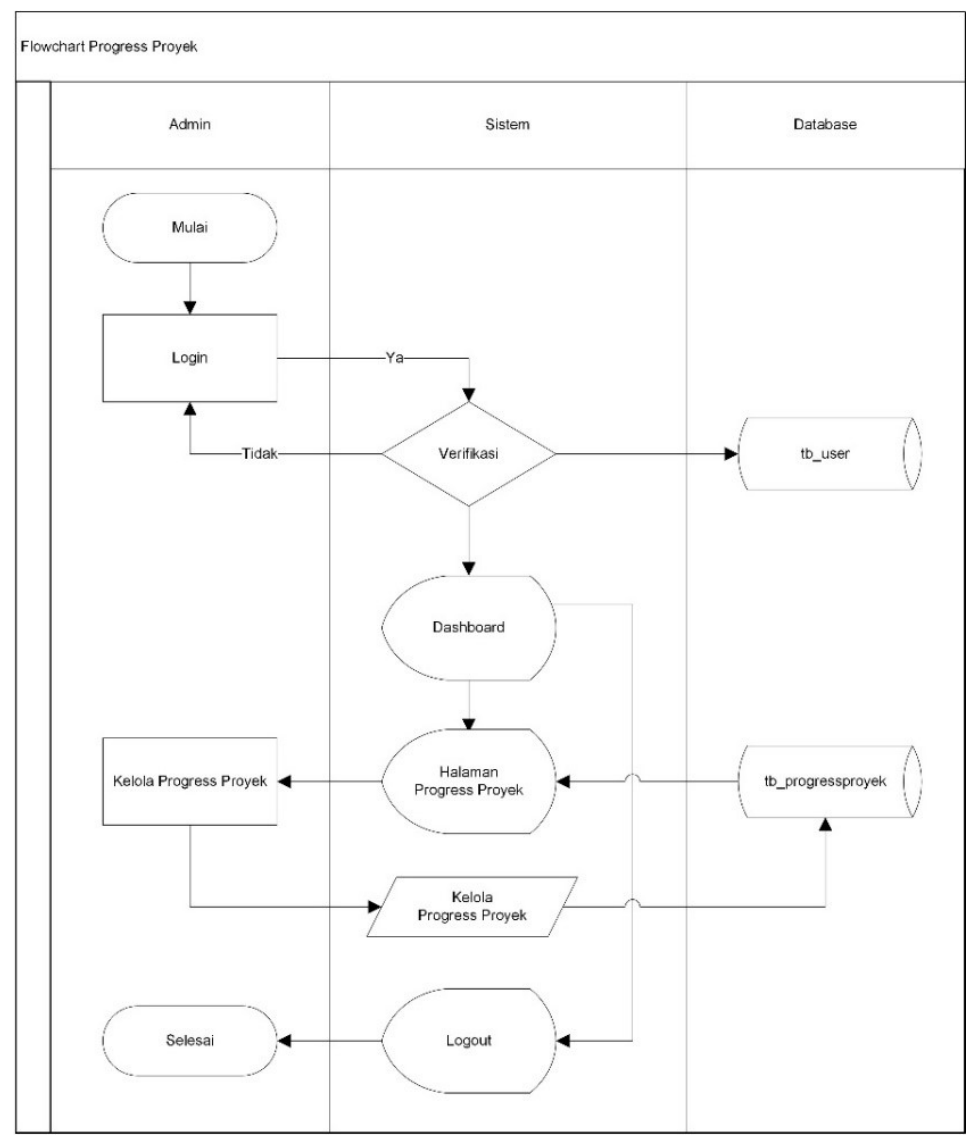

Gambar 4. Flowchart progress proyek yang diusulkan

\subsubsection{Diagram Aliran Data}

\section{Diagram Konteks}

Berdasarkan flowchart sistem yang diusulkan, maka peneliti memberikan gambaran arus data terhadap sistem yang diusulkan berupa diagram konteks dapat dilihat pada Gambar 5.

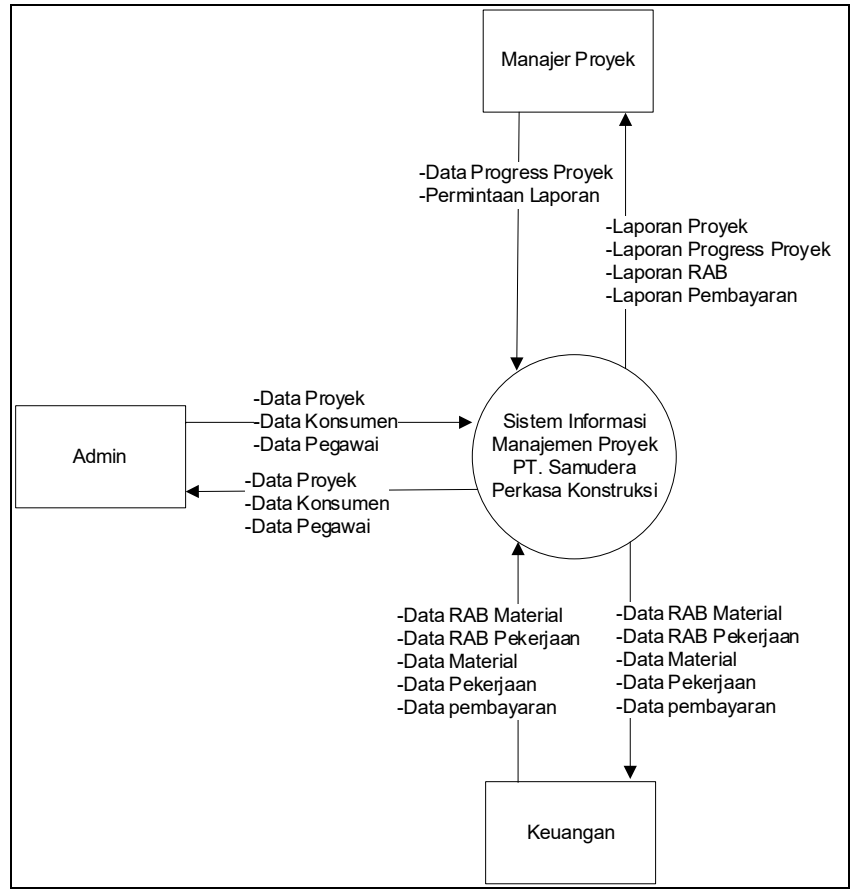

Gambar 5. Diagram konteks

Matrik : Jurnal Manajemen, Teknik Informatika dan Rekayasa Komputer

Vol. 20, No. 1, November 2020: 85 96 
Berdasarkan Gambar 5, diagram konteks dijelaskan sebagai berikut:

1. Admin akan menginput data proyek, data konsumen, data pegawai, setelah menginput data, admin juga bisalangsung melihat data yang sudah diinput seperti data proyek, data konsumen, data pegawai, progress proyek.

2. Keuangan akan menginput data material, data pekerjaan, data RAB material, data RAB pekerjaan, pembayaran, keuangan juga bisa langsung melihat data yang sudah diinput seperti data yang sudah diinput.

3. Manajer Proyek akan menginput data progress proyek dan menerima laporan seperti laporan data proyek, progress proyek, RAB, dan laporan pembayaran.

\section{Entity Relationship Diagram}

Entity Relationship Diagram (ERD) adalah gambar atau diagram yang menunjukkan informasi dibuat, disimpan, dan digunakan dalam sistem bisnis [15]. Entity Relationship Diagram merupakan model konseptual yang menggambarkan hubungan antar penyimpanan data, merupakan alat untuk mendefinisikan hubungan antara penyimpanan data [ㅌ]. Berdasarkan uraian diatas dapat disimpulkan bahwa ERD adalah gambar atau diagram yang menunjukkan informasi dibuat disimpan dan digunakan untuk memodelkan struktur data dan hubungan antar data.

Desain ERD yang berisi komponen-komponen himpunan entitas dan himpunan relasi yang masingmasing dilengkapi atribut-atribut. Entitas terdir idari 9 entitas yaitu entitas RAB, material, keuangan, pembayaran, manajer proyek, admin, konsumen, proyek, progress proyek. ERD yang diusulkan disajikan pada Gambar 6.

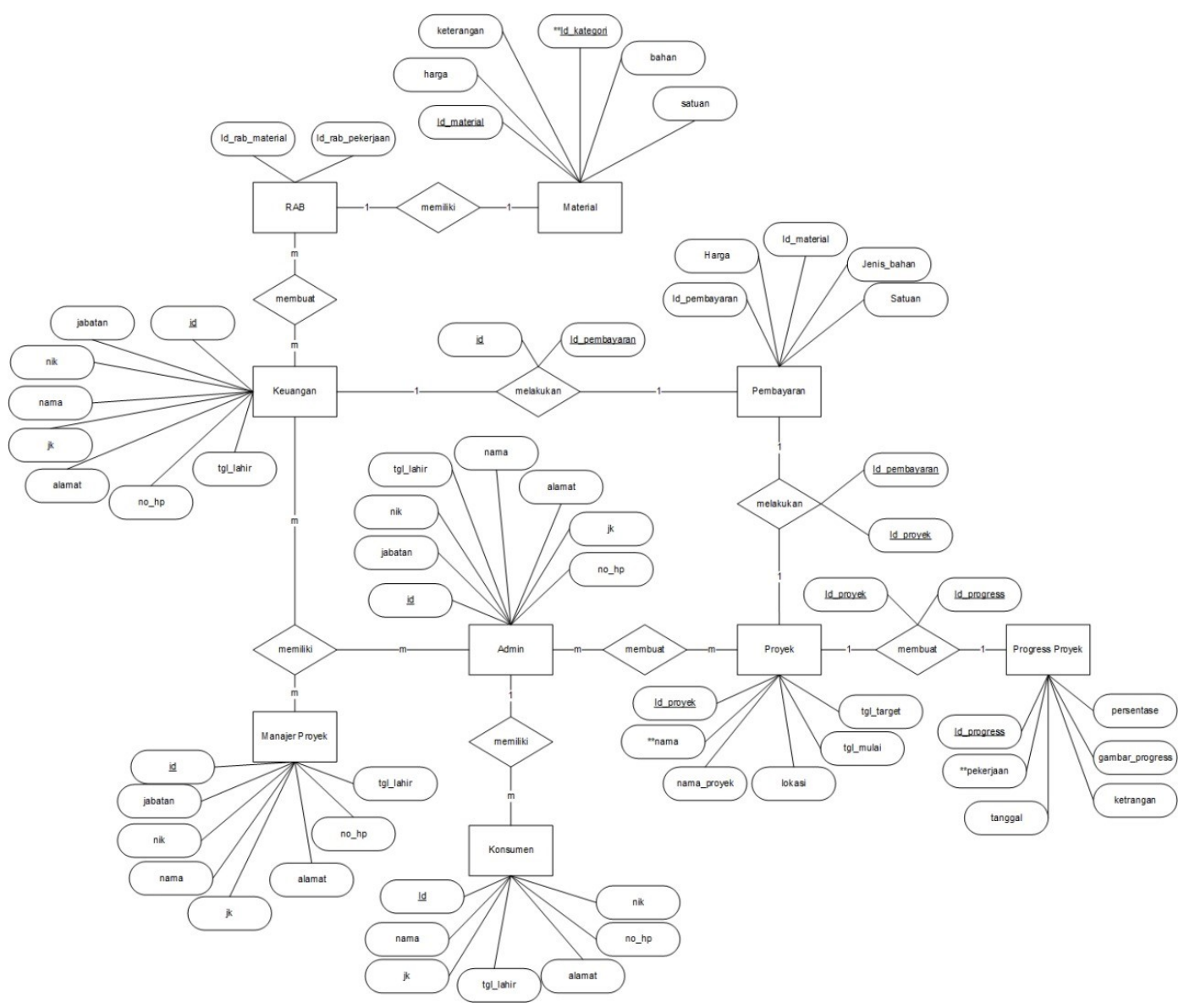

Gambar 6. Entity Relationship Diagram (ERD) 


\subsubsection{Construction}

Tahapan construction (konstruksi) dilakukan berdasarkan data yang telah didapat dari tahap sebelumnya.Adapun construction yang diterapkan berupa sistem yang dibangun seperti antarmuka-antarmuka berikut.

Tampilan dashboard admin diperlihatkan pada Gambar 7. Tampilan halaman dashboard admin memiliki menu dashboard, pegawai, konsumen, dan proyek.

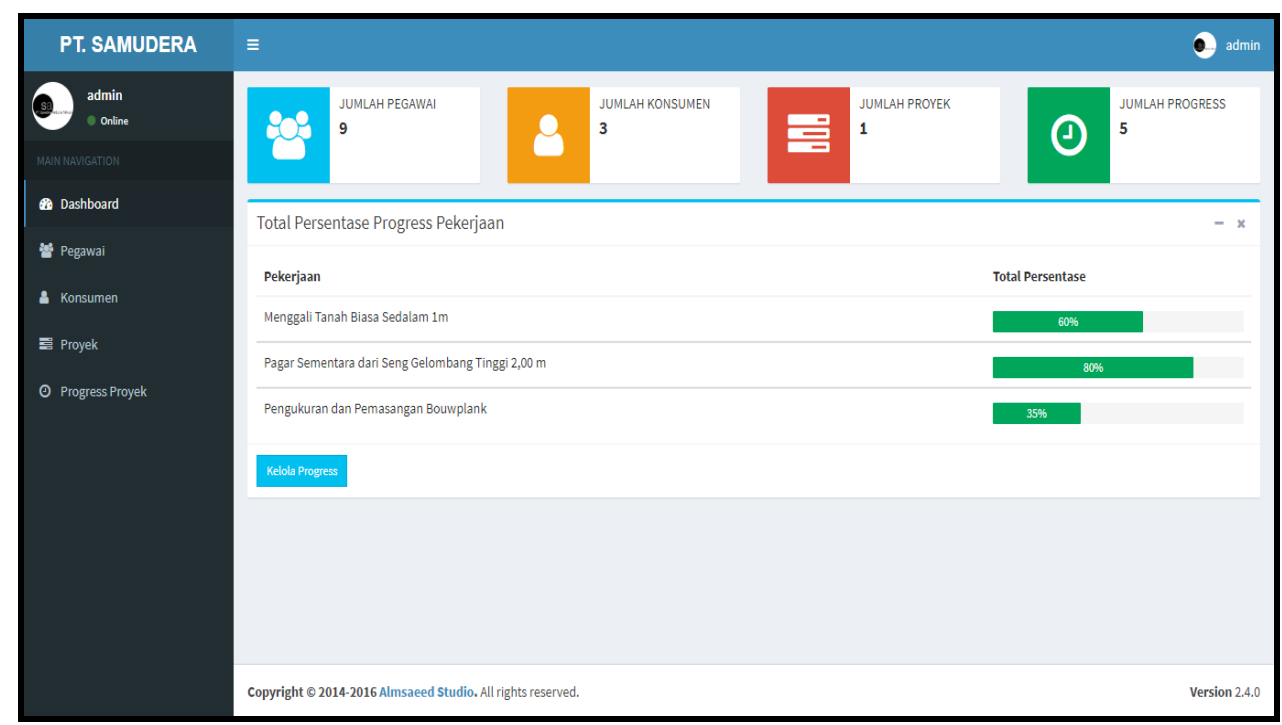

Gambar 7. Tampilan dashboard admin

Tampilan dashboard keuangan diperlihatkan pada Gambar 8.

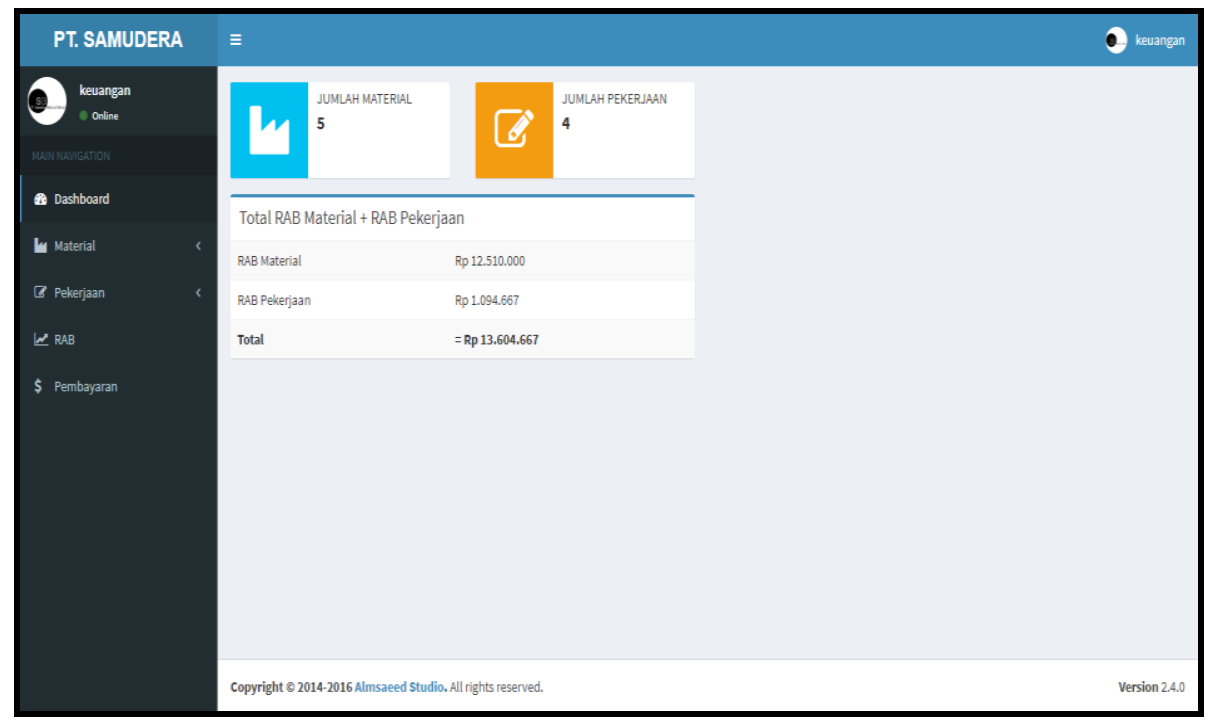

Gambar 8. Tampilan dashboard keuangan

Tampilan dashboard manajer proyek diperlihatkan pada Gambar 9. Tampilan dashboard manajer proyek terdapat print data proyek, progress proyek, rab, dan pembayaran, dan menampilkan total progress proyek. 


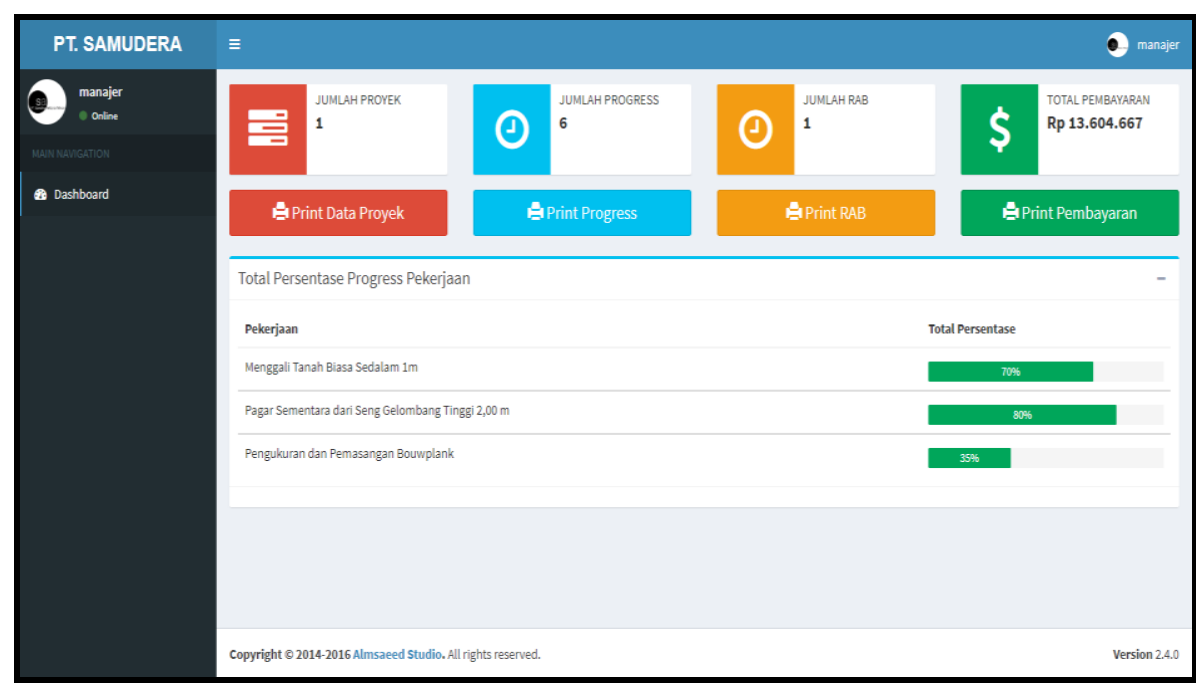

Gambar 9. Tampilan manajer proyek

Tampilan kelola proyek diperlihatkan pada Gambar 10. Tampilan halaman kelola kelola proyek dalam hal ini menu kelola proyek dapat menambah, mengubah, dan menghapus. Data pengajuan dalam tabel terdapat file berupa nama konsumen, nama proyek, tanggal mulai, tanggal target, lokasi, dan aksi.

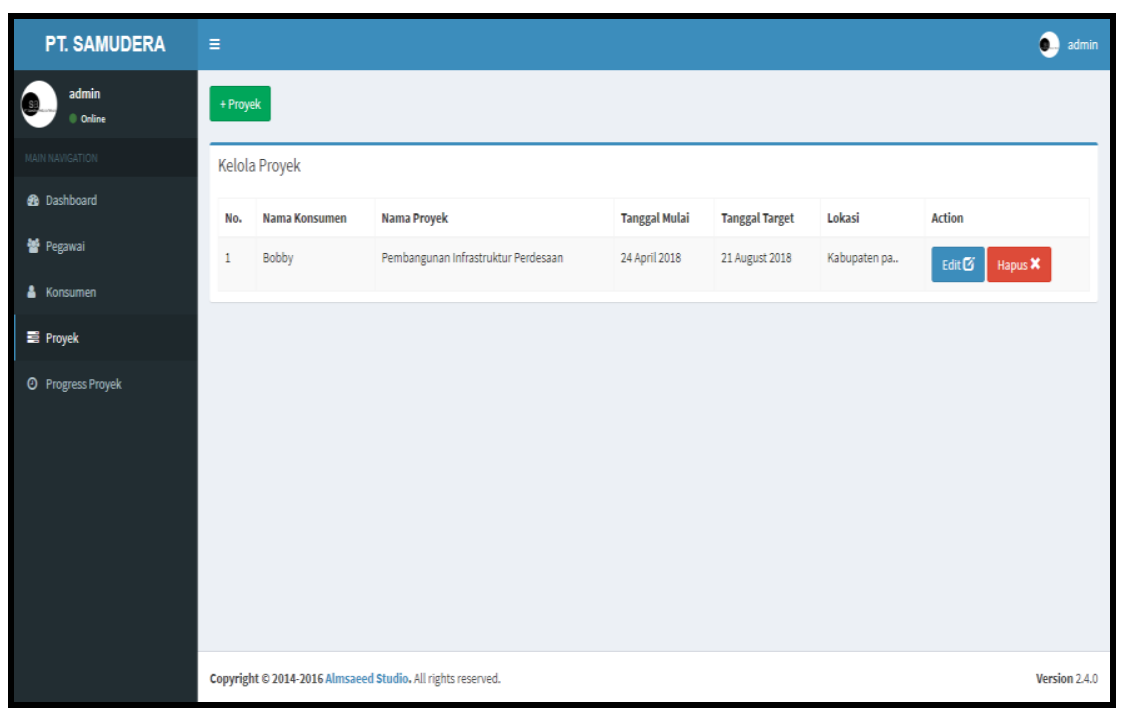

Gambar 10. Tampilan kelola proyek

Tampilan tambah proyek diperlihatkan pada Gambar 11. Tampilan halaman tambah proyek digunakan untuk menambahkan data proyek.

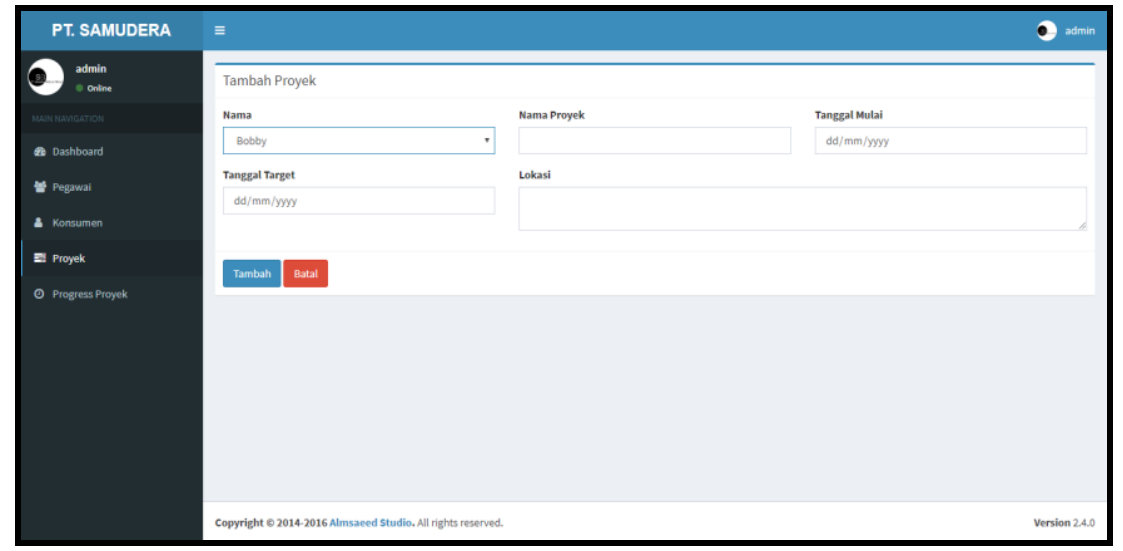

Gambar 11. Tampilan tambah proyek 
Tampilan kelola progress proyek diperlihatkan pada Gambar 12. Tampilan kelola progress dalam hal ini menu pengajuan dapat menambah, dan menghapus. data progress proyek di dalam tabel terdapat beberapa file berupa pekerjaan, tanggal, gambar, preview gambar, keterangan, dan aksi.

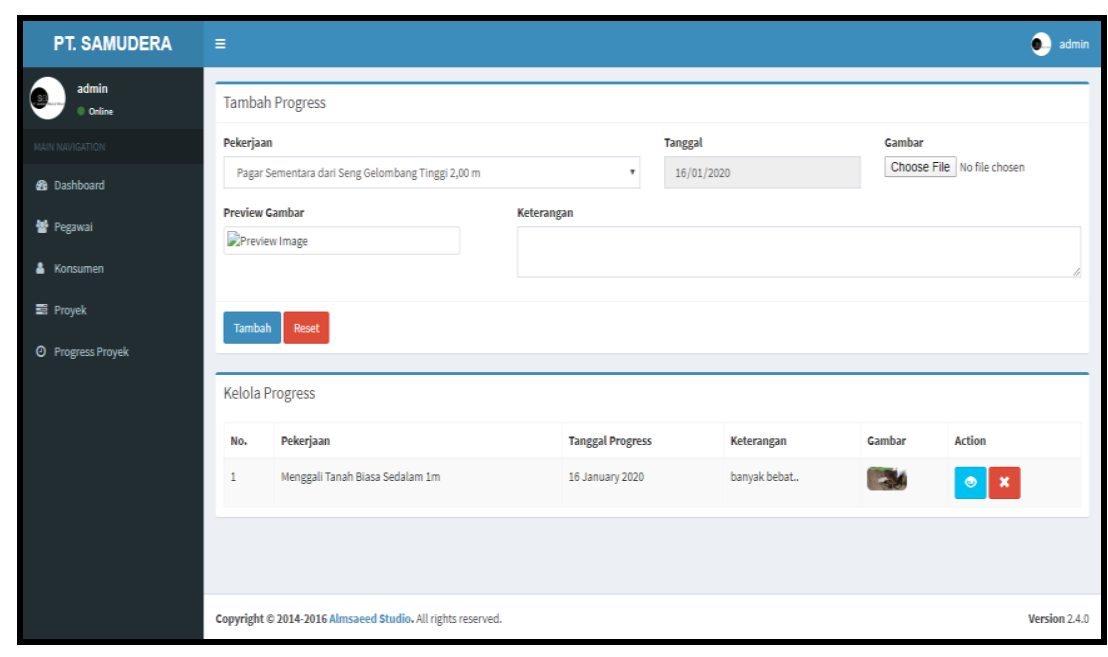

Gambar 12. Tampilan kelola progress proyek

Setelah tahap construction dilakukan maka tahap selanjutnya peneliti melakukan pengujian perangkat lunak dengan menggunakan metode blackbox. Pengujian ini berfokus pada persyaratan fungsional perangkat lunak yang memperhatikan masukan ke dalam sistem dan keluaran dari masukan tersebut. Metode ini digunakan untuk mengetahui apakah sistem berfungsi dengan benar. Berikut merupakan rancangan dari masukan pada sistem informasi manajemen proyek PT. Samudera Perkasa Konstruksi berbasis web.

Pengujian blackbox login user dapat dilihat pada Tabel 1 dan pengujian halaman proyek dapat dilihat pada Tabel 2. Hasil pengujian perangkat lunak masukan ke dalam sistem dan keluaran dari masukan dinyatakan sukses yang berarti bahwa setiap sistem berfungsi dengan baik. Sistem informasi manajemen proyek selanjutnya dapat digunakan oleh pengguna.

Tabel 1. Pengujian BlackboxLogin

\begin{tabular}{|c|c|c|c|}
\hline Rancangan Proses & Hasil Yang Diharapkan & Hasil & Ket \\
\hline $\begin{array}{l}\text { Form login dan klik tombol login jika } \\
\text { username dan password valid }\end{array}$ & Masuk ke halaman Dashboard & Sukses & Jika input benar \\
\hline $\begin{array}{l}\text { Form login dan klik tombol login jika } \\
\text { username dan password tidak valid }\end{array}$ & Kembali ke halaman login & Sukses & Jika input salah \\
\hline
\end{tabular}

Tabel 2. PengujianBlackbox Halaman Proyek

\begin{tabular}{llll}
\hline Rancangan proses & Hasil Yang Diharapkan & Hasil & Ket \\
\hline Klik menu proyek & Tampil halaman data proyek & Sukses & Tampil halaman data proyek \\
Klik tambah proyek & Tampil form tambah proyek & Sukses & Tampil form tambah proyek \\
Klik tombol tambah & Tampil pesan konfirmasi & Sukses & Tampil pesan konfirmasi \\
Klik edit proyek & Tampil halaman form edit proyek & Sukses & Tampil halaman form edit proyek \\
Klik tombol edit & Tampil pesan konfirmasi & Sukses & Tampil pesan konfirmasi \\
Klik hapus proyek & Tampil dialog konfirmasi hapus & Sukses & Tampil dialog konfirmasi hapus \\
plik tombol hapus & Tampil pesan konfirmasi & Sukses & Tampil pesan konfirmasi \\
\hline
\end{tabular}




\subsubsection{Deployment}

Pada tahap deployment penulis melakukan pengujian dengan user dan melakukan hosting sementara, hal ini dimaksudkan untuk melihat sejauh mana sistem yang dibuat berjalan sesuai yang diharapkan, selain itu penulis juga memberikan pelatihan kepada pengguna di PT. Samudera Perkasa Konstruksi serta meminta feedback atau saran terkait pengembangan sistem dimasa yang akan datang.

Berdasarkan penjabaran hasil dari metode waterfall yaitu spesifikasi kebutuhan pengguna (communication), melalui tahap perencanaan (planning), pemodelan (modeling), konstruksi (construction), serta pada saat penyerahan sistem ke pengguna atau pelanggan (deployment), yang diakhiri dengan dukungan dari pihak perusahaan berkelanjutan pada sistem yang dihasilkan. Dokumentasi penyerahan website dapat di lihat pada Gambar 13.

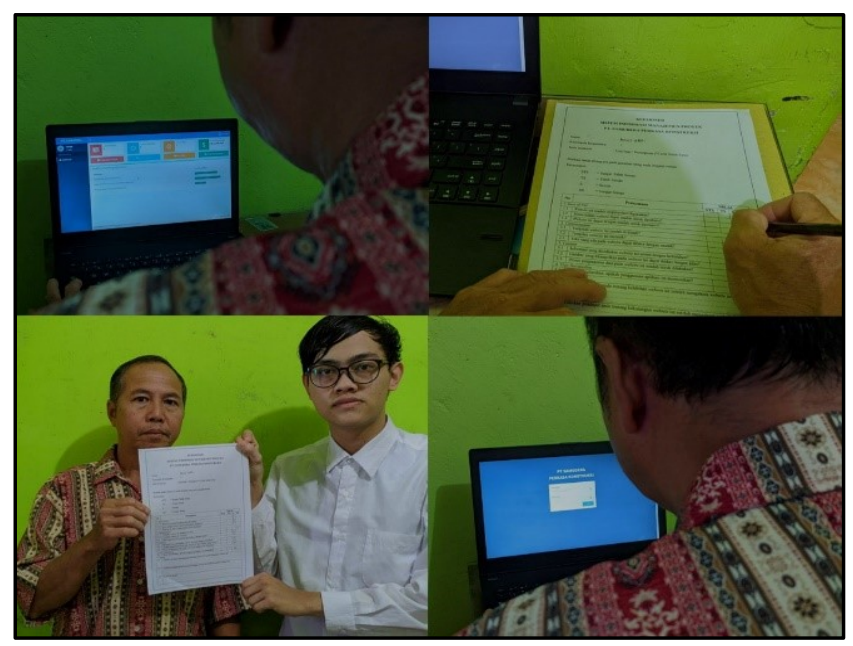

Gambar 13. Dokumentasi serah terima website

Masing-masing tahapan tersebut didokumentasikan dalam bentuk persiapan kebutuhan sistem informasi manajemen proyek, flowchart, data flow diagram, entity relationship diagram, dan membuat rancangan desain interface, relasi antar tabel dan interface perangkat lunak sistem. Berdasarkan pengujian yang telah dilakukan membuktikan bahwa perangkat lunak yang dibangun sesuai dengan tujuan awal yaitu membuat sistem informasi manajemen proyek PT.Samudera Perkasa Konstruksi berbasis web.

\section{KESIMPULAN}

Adapun kesimpulan dari penelitian ini adalah sistem informasi manajemen proyek yang dibangun dapat mengelola data proyek, progress proyek, data RAB, data konsumen, data pegawai, data material, data pekerjaan, dan pembayaran. Dengan adanya sistem informasi manajemen proyek ini dapat mempermudah pegawai, dalam mengelola data seputar proyek dengan mudah, cepat, akurat dan tercatat otomatis kedalam sistem. Berdasarkan permasalahan yang ada peneliti memberikan saran untuk langkah pengembangan selanjutnya yaitu sistem menampilkan jadwal proyek dan analisis jadwal proyek. Kemudian melakukan backup data secara berkala untuk meminimalisasikan kemungkinan hilangnya data-data dari kejadian-kejadian yang tidak diharapkan.

\section{REFERENSI}

[1] K. C. Laudon and J. P. Laudon, Management Information Systems: Managing the Digital Firm, 12th ed. New Jersey: Prentice Hall, 2012.

[2] M. Destiningrum and Q. J. Adrian, "Sistem Informasi Penjadwalan Dokter Berbassis Web dengan Menggunakan Framework Codeigniter (Studi Kasus: Rumah Sakit Yukum Medical Centre)," Jurnal Teknoinfo, vol. 11, no. 2, p. 30, 2017.

[3] A. R. Hidayatullah and M. R. Arief, "Analisis dan Perancangan Sistem Informasi Manajemen Zakat Berbasis Client Server pada Badan Amil Zakat Masjid Agung Baitul Qadim Loloan Timur," Seminar Nasional Teknologi Informasi dan Multimedia, vol. 4, no. 1, pp. 103-108, 2016.

[4] E. Setiawan, "Manajemen Proyek Sistem Informasi Penggajian Berbasis Web," Jurnal Teknik, vol. 17, no. 2, pp. 84-93, 2019.

[5] B. Hartono, Sistem Informasi Manajemen Berbasis Komputer. Jakarta: Rineka Cipta, 2013.

[6] J. Ariska and M. Jazman, "Rancang Bangun Sistem Informasi Manajemen Aset Sekolah Menggunakan Teknik Labelling QR Code (Studi Kasus: MAN 2 Model Pekanbaru)," Jurnal Ilmiah Rekayasa dan Manajemen Sistem Informasi, vol. 2, no. 2, pp. 127-136, 2016. 
[7] I. Heryanto, Manajemen Proyek Berbasis Teknologi Informasi Mengelola Proyek Secara Sistematis Menggunakan Microsoft Project. Bandung: Informatika, 2015.

[8] L. M. Rompas, "Penerapan Teknologi pada Sistem Informasi Manajemen Proyek Sistem Informasi Kontraktor dan Konsultan (Studi Kasus Kota Manado),” Tekno, vol. 18, no. 74, pp. 101-112, 2020.

[9] J. Cordeaux, "“Wicks' of the mouth," Notes and Queries, vol. s5-VII, no. 159, p. 37, 1877.

[10] D. S. Budi, T. A. Y. Siswa, and H. Abijono, "Analisis Pemilihan Penerapan Proyek Metodologi Pengembangan Rekayasa Perangkat Lunak,” Teknika, vol. 5, no. 1, pp. 24-31, 2017.

[11] H. Setiawan and M. Q. Khairuzzaman, "Perancangan Sistem Informasi Manajemen Proyek: Sistem Informasi Kontraktor,” Jurnal Khatulistiwa Informatika, vol. 5, no. 2, pp. 103-111, 2017.

[12] P. Setiawan, S. Sulistiowati, and J. Lemantara, "Rancang Bangun Aplikasi Pengolahan Data Evaluasi Proses Belajar Mengajar Berbasis Web pada STIKES Yayasan RS. Dr. Soetomo Surabaya,” 2015.

[13] R. S. Pressman, Rekayasa Perangkat Lunak, 1st ed. Yogyakarta: Andi Offset, 2015.

[14] L. Sitorus, Algoritma dan Pemrograman. Yogyakarta: Andi Offset, 2015.

[15] S. Santoso and R. Nurmalina, "Perencanaan dan Pengembangan Aplikasi Absensi Mahasiswa Menggunakan Smart Card Guna Pengembangan Kampus Cerdas (Studi Kasus Politeknik Negeri Tanah Laut)," Jurnal Integrasi, vol. 9, no. 1, pp. 84-91, 2017.

[16] F. Fatmawati and J. Munajat, "Implementasi Model Waterfall Pada Sistem Informasi Persediaan Barang Berbasis Web (Studi Kasus: PT.Pamindo Tiga T)," Jurnal Media Informatika Budidarma, vol. 2, no. 2, pp. 1-9, Apr. 2018. 